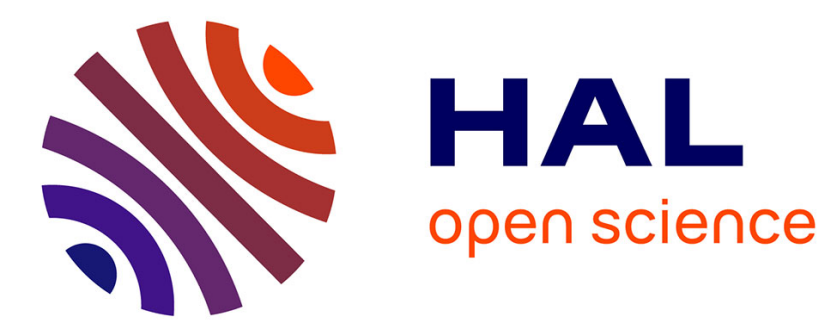

\title{
Carboniferous Blattinopsidae: revision of Klebsiella and new genus and species from Avion (Insecta, Paoliida)
} Laura Quispe, Patrick Roques, Romain Garrouste, André Nel

\section{To cite this version:}

Laura Quispe, Patrick Roques, Romain Garrouste, André Nel. Carboniferous Blattinopsidae: revision of Klebsiella and new genus and species from Avion (Insecta, Paoliida). Historical Biology, 2021, 34 (3), pp.383-389. 10.1080/08912963.2021.1916817 . hal-03232048

\section{HAL Id: hal-03232048 \\ https://hal.sorbonne-universite.fr/hal-03232048}

Submitted on 21 May 2021

HAL is a multi-disciplinary open access archive for the deposit and dissemination of scientific research documents, whether they are published or not. The documents may come from teaching and research institutions in France or abroad, or from public or private research centers.
L'archive ouverte pluridisciplinaire HAL, est destinée au dépôt et à la diffusion de documents scientifiques de niveau recherche, publiés ou non, émanant des établissements d'enseignement et de recherche français ou étrangers, des laboratoires publics ou privés. 
Historical biology

2

3 Carboniferous Blattinopsidae: revision of Klebsiella and new genus and species from Avion 4 (Insecta, Paoliida)

5

Laura Quispe $^{\mathrm{a}}$, Patrick Roques ${ }^{\mathrm{b}}$, Romain Garrouste ${ }^{\mathrm{c}}$ and André $\mathrm{Nel}^{\mathrm{c}, *}$

7

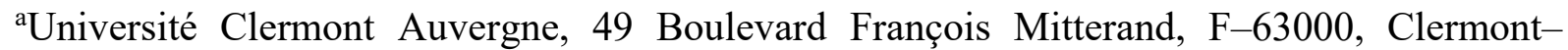

F-93049, France. E-mail: patrick.roques93@wanadoo.fr; 'Institut de Systématique, Évolution,

Biodiversité, ISYEB - UMR 7205 - CNRS, MNHN, UPMC, EPHE, Muséum national d'Histoire naturelle, Sorbonne Universités, 57 rue Cuvier, CP 50, Entomologie, F-75005, Paris, France. E-mails: garroust@mnhn.fr, anel@mnhn.fr

* Corresponding author confirming its attribution to the Blattinopsidae. The family name Klebsiellidae should have priority on its junior synonym Blattinopsidae, but the common usage over time could allow maintaining the later. The first Blattinopsidae from the Moscovian Konservat-lagerstätte of Avion is described as a new genus and species Avionblattinopsis oudardi gen. et $\mathrm{n}$. sp. on the basis of a single forewing. It differs from the other genera of this family in the vein ScP distally fused to the vein RA. It increases our knowledge about this family, known between the Late 
Protoblattiniella minutissima Meunier, 1912, based on a mature nymph would better fit with the Paoliidae than with the Blattinopsidae.

\section{KEYWORDS}

Neoptera; Polyneoptera; wing venation; gen. et n. sp.; Moscovian; France.

\section{Introduction}

The small Paleozoic polyneopteran family Blattinopsidae currently contains 11 genera, but only four can be accurately considered as informative because six are based on very fragmentary fossils and one could be related to another group. Carpenter (1992) put the Blattinopsidae into the so-called 'Protorthoptera', Béthoux and Nel (2002) and Béthoux et al. (2009) supposed they were related to the Dictyoptera, but Béthoux and Jarzembowski (2010) considered that they were Archaeorthoptera sensu Béthoux and Nel (2002). More recently, Prokop et al. (2014a) included them in the Paoliida (as sister group of the Dictyoptera), on the basis of putative wing venation synapomorphies. These insects are mainly known and characterized by their wing venation, the body structures being either absent or poorly preserved. They are recorded between the Late Carboniferous and the early Middle Permian from Europe and North America. The Blattinopsidae were still unrecorded in the Konservat-lagerstätte of Avion, while this outcrop has already given an important diversity of insects, including Palaeodictyoptera, Diaphanopterodea, Odonatoptera, Archaeorthoptera, Caloneurodea, Paoliida, Dictyoptera, Plecoptera, Acercaria, and Holometabola (Nel et al. 2013, Prokop et al. 2013, 2014b, Coty et al. 2014; Schubnel et al. 2019a,b).

\section{Material and methods}


The imprint was prepared with a pneumatic hammer. It was observed under a Nikon SMZ1500 binocular microscope, photographed using a Nikon D800 and drawn using a camera lucida. The fossil insects were found in 'Terril N 7', a slag heap located in the Avion area comprising Moscovian-aged sediments derived from Liévin coal mines 3 and 4, specifically the Bolsovian or Westphalian C (311-308 Myrs) 'faisceaux de Ernestine', and the Asturian or Westphalian D (308-306 Ma) 'veines Arago, Dusouich, Marthe' informal beds (Bruno Vallois pers. comm.). Wing venation nomenclature follows Prokop et al. (2014a) and Schubnel et al. (2019c), especially concerning the presence of a postcubital veins in Pterygota. Abbreviations are as follows: arc arculus reinforced oblique crossvein between $\mathrm{M}$ and $\mathrm{CuA} ; \mathrm{C}$ costal vein; $\mathrm{ScP}$ subcostal posterior; RA radius anterior; RP radius posterior; $\mathrm{M}$ median vein; $\mathrm{CuA}$ cubitus anterior; $\mathrm{CuP}$ cubitus posterior; $\mathrm{PCu}$ postcubital vein; A anal vein(s).

Abbreviation for institution: MNHN Muséum National d'Histoire Naturelle de Paris, France. urn:1sid:zoobank.org:pub:4EA5FC20-6DE0-41A8-9227-7049E3C60928

\title{
Systematic palaeontology
}

Order: Paoliida Handlirsch (1906)

\section{Remark}

The Paoliida currently comprise the three families Paoliidae Handlirsch, 1906, Anthracoptilidae Handlirsch, 1922, and Blattinopsidae Bolton, 1925.

\author{
Family: Blattinopsidae Bolton (1925)
}

Type genus. Blattinopsis Giebel, 1867 
Other genera (after Fossilworks database). Alienus Handlirsch, 1906, Balduriella Meunier, 1925, Glaphyrophlebia Handlirsch, 1906, Klebsiella Meunier, 1908, Microblattina Scudder, 1896, Protoblattiniella Meunier, 1912, Rhipidioptera Brongniart, 1893, Stephanopsis Kukalová, 1958, Westphaloblattinopsis Béthoux and Jarzembowski, 2010.

\section{Remarks}

The genus Protociccus, listed in the Fossilworks database, was synonymized with Glaphyrophlebia by Hörnschemeyer and Stapf (2001).

We confirm below the attribution of the genus Klebsiella (type genus of the Klebsiellidae Handlirsch, 1919) to the same family as Blattinopsis. The name Klebsiellidae, as a valid and older family name, should have priority on the name Blattinopsidae Bolton, 1925. Nevertheless, we prefer to maintain the prevailing usage of names until the Commission of nomenclature will decide on this case.

Bolton (1925: 23) proposed the following diagnosis for the Blattinopsidae: 'Protoblattoidea with elongated, oval wings, folding backwards over the body. Radius (R \& RA) strong and elevated basally, distally ending in feeble branches. Radial sector (RP) much branched. Median (M) arising from the radius or radial sector in two or more branches. Cubitus $(\mathrm{Cu})$ two or three times branched. Anal area large, with few anal veins. Interstitial neuration a close reticulation, developing accessory veins along the distal inner and apical margins of the wing'. This diagnosis is not enough precise to characterize the family. Carpenter (1992: 103, fig. 59.10a) proposed another diagnosis: 'Fore wing with vein $\mathrm{SC}(\mathrm{ScP})$ terminating on costal margin well before apex; R (R \& RA) usually sigmoidally curved, numerous oblique veinlets between R and costal margin beyond SC; RS (RP) with numerous branches; MA apparently absent; MP (M) often with one or more branches anastomosed with R or RS; CUA (CuA) anastomosed with basal portion of $\mathrm{M}$, diverging away, and then fusing with CUA2; strong indentation at end 
of CUP (CuP); anal veins straight; crossveins numerous, commonly forming meshwork of cells. Hind wing unknown.' This diagnosis is erroneous in an important point: Carpenter considered that 'CUA' $(\mathrm{CuA})$ is basally fused with $\mathrm{M}$ and emerges from it to fuse with 'CUA2', but, as already noticed by Prokop et al. (2014a), $\mathrm{CuA}$ is the convex anterior branch of $\mathrm{Cu}$ and the socalled 'CUA' is a reinforced crossvein (arculus) between $\mathrm{M}$ and $\mathrm{CuA}$. Thus we propose a new diagnosis for the Blattinopsidae, as follows: forewing with $\mathrm{ScP}$ ending into $\mathrm{C}$ or in $\mathrm{RA}$; numerous crossveins between the main longitudinal veins; R (RA) sigmoidally curved; numerous posterior branches of RP, pectinate; a reinforced crossvein 'arculus' between $\mathrm{M}$ and $\mathrm{CuA}$; a common stem $\mathrm{Cu}$ from which convex $\mathrm{CuA}$ and concave $\mathrm{CuP}$ separate distally; one concave anterior branch of $\mathrm{CuA}$; broad area between $\mathrm{CuA}$ and $\mathrm{CuP}$ with numerous crossveins; area between $\mathrm{CuP}$ and $\mathrm{PCu}$ narrow; $\mathrm{CuP}$ and $\mathrm{PCu}$ basally curved and distally straight; area between $\mathrm{PCu}$ and first anal vein broad with a net of irregular cells; three anal veins.

The monotypic genus Klebsiella (K. exstincta Meunier, 1908), based on a specimen (MNHN.F.R51219) showing a forewing and the distal half of another (hind?) wing. It was very schematically drawn by Meunier (1908: fig. 2). Handlirsch (1919: 552, fig. 52) proposed the family Klebsiellidae for this genus, and re-drawned its wings. Handlirsch's diagnosis was rather precise, viz. 'Errichtet auf ein Fossil aus Commentry, welches in mancher Hinsicht etwas an die mit Oedischia verwandten Formen erinnert, aber in anderer Hinsicht wieder Charaktere der Protoblattoiden erkennen läßt. Die Flügel sind relativ breit mit verkürzter Subcosta, die namentlich im Vorderflügel ein breites Costalfeld begrenzt. Der Radius sendet eine Anzahl kurzer Ästchen zum Costalrand, sein Sector ist in normaler Weise reich verzweigt. Auch die beiden Äste der Medialis sind wiederholt gegabelt. Der Cubitus dagegen bildet nur drei bis vier Zweige. Das Analfeld war relativ groß und nach vorne fast geradlinig begrenzt, im Hinterflügel bildete es einen kleinen Fächer. Queradern schütter', translated as follows: 'Erected on a fossil from Commentry, which in some ways reminds us of the forms related to Oedischia, but in 
other ways reveals characters of the protoblattoids. The wings are relatively wide with a shortened subcostal ( $\mathrm{ScP})$, which, in particular, limits a wide costal area in the forewing. The radius (RA) sends a number of short branches to the costal margin, its sector (RP) is normally richly branched. The two branches of the media (M) are also forked repeatedly. The cubitus, on the other hand, only forms three to four branches. The anal area was relatively large and almost straight forward, it formed a small fan in the hind wing. Sparse crossveins'. This diagnosis is also not sufficient for an accurate determination of the family. Nevertheless, the family Klebsiellidae is valid because there were a diagnosis and designations of a type genus and species. Bolton (1925: 25) indicated: 'The genus Klebsiella Meunier (June 1908) was founded upon the distal two-thirds of what appear to be the fore and hind wings of one side. The radius terminates as in Blattinopsis, the radial sector is broken away over the area $\mathrm{m}$ which it should join the radius, and neither wing shows the relation of the median and radius. The general branching of the median, cubitus, and anal is similar to that of Blattinopsis, and there seems no satisfactory reason why the wings should be placed in a distinct genus'. Apparently Bolton (1925) ignored the work of Handlirsch (1919) that he did not cite. Carpenter (1992: 133) considered Klebsiella as a 'Prothoptera' of 'family uncertain'. Later, Hornschemeyer and Stapf (2001) attributed Klebsiella to the Blattinopsidae without further argument and no discussion on the family Klebsiellidae. In the internet site 'Fossilworks' (http://fossilworks.org/?a=taxonInfo\&taxon_no=271212), the family Klebsiellidae is considered as an 'invalid subtaxon' of the Blattinopsidae, without precise reason.

Thus we need first to redescribe Klebsiella, in order to precise its affinities with Blattinopsis. 
Type species

Klebsiella exstincta Meunier, 1908

New diagnosis. Forewing characters only. ScP rather long, extending beyond mid wing level, strongly approximating RA before its apex into C; area between ScP and R not extremely narrow, nearly as wide as area between $\mathrm{ScP}$ and $\mathrm{C}$; radial vein making a pronounced angle at base of RP, no reticulation in areas between main veins, especially in distal half of wing but only a few crossveins connecting branches of RP and M; area between RA and RP rather narrow; no distinct longitudinal furrows between branches of RP and M; area between CuA and $\mathrm{CuP}$ slightly broader than that between $\mathrm{M}$ and $\mathrm{CuA}$; a concave distal anterior branch of $\mathrm{CuA}$ but no long posterior branches in area between $\mathrm{CuA}$ and $\mathrm{CuP}$; postcubital-anal area not reticulated, with only four main veins.

Klebsiella exstincta Meunier, 1908

(Figures 1-2)

\section{Type material}

MNHN.F. R51219 (imprint and counterimprint of a forewing with a part of another (hind?) wing and fragments of body, possibly a very long and curved ovipositor, see arrow in Fig. 1).

\section{Type locality}

Commentry, Allier, France.

\section{Stratigraphic occurrence}

Gzehlian, Late Carboniferous. 
175

176

177

178

179

180

181

182

183

184

185

186

187

Description

Forewing $32.6 \mathrm{~mm}$ long, $10.4 \mathrm{~mm}$ wide; with extreme bases of $\mathrm{RP}, \mathrm{M}, \mathrm{Cu}, \mathrm{PCu}$ and anal vein not well preserved; except for sinuate R-RA and ScP, longitudinal veins and branches straight and evenly spaced, often parallel to a marked degree; vein ScP rather long, strongly approximating RA, but ending on $\mathrm{C}$ at $24.3 \mathrm{~mm}$ from wing base; area between ScP and RA rather broad, only slightly narrower than area between $\mathrm{C}$ and ScP; RA sinuate and terminating $29.8 \mathrm{~mm}$ from wing base, RP separating from RA at ca. $10.0 \mathrm{~mm}$ from wing base, RP with a first fork $5.3 \mathrm{~mm}$ from its base, posterior branch forked twice, anterior branch forked again distally, with posterior branch forked and anterior one forked again twice; $\mathrm{M}$ forked $4.3 \mathrm{~mm}$ from its base, anterior branch with three branches; posterior branch forked two times; no longitudinal furrows between branches of RP and MP; few simple crossveins in RP/M area; $\mathrm{M}$ emerging from a common stem $\mathrm{R}+\mathrm{M}$; $\mathrm{CuA}$ with one concave anterior branch and no convex posterior branches; area between $\mathrm{CuA}$ and $\mathrm{M}$ as wide as that between $\mathrm{CuA}$ and $\mathrm{CuP}$; oblique convex arculus not preserved (if present) in area between $\mathrm{M}$ and $\mathrm{CuA} ; \mathrm{CuA}$ and $\mathrm{CuP}$ separating from a common stem well separated from $\mathrm{M}$ and $\mathrm{PCu}$; $\mathrm{CuP}$ curved at base and straight and strongly concave, while $\mathrm{PCu}$ strongly convex and curved; a short neutral vein between $\mathrm{Cu}$ and $\mathrm{PCu}$ at wing base; in postcubital-anal area, nearly all crossveins all simple, four main veins, all simple, except penultimate one with three branches; network of cells generally lacking except in areas between $\mathrm{M}$ and $\mathrm{CuA}$ and below $\mathrm{PCu}$.

\section{Remark}

Klebsiella can be attributed to the order Paoliida sensu Prokop et al. (2014a) because of the following characters: concave $\mathrm{ScP}$ approximating RA in distal half of wing; strongly convex RA with weak, short but distinct anterior branches, unusually prominent steep elevation from 
$\mathrm{ScP}$ to RA forming a characteristic wing profile; costal area between ScP and costal margin with series of simple, oblique veinlets; RP rather concave with numerous branches; M rather concave; convex $\mathrm{CuA}$ and concave $\mathrm{CuP}$ separating from a rather long basal stem $\mathrm{Cu}$; $\mathrm{CuA}$ not in contact with the stem $\mathrm{R}+\mathrm{M}$; area between $\mathrm{CuP}$ and $\mathrm{CuA}$ broad compared to median and radial areas (autapomorphy), a general course of CuA making a double curve (autapomorphy); $\mathrm{CuA}$ has convex posterior branches, plus some weaker concave anterior branches; $\mathrm{CuP}$ simple, nearly straight; anal fan strongly reduced.

Affinities with the Paoliidae are excluded because the area between $\mathrm{CuA}$ and $\mathrm{CuP}$ is not very broad, just slightly broader than area between $\mathrm{CuA}$ and $\mathrm{M}$ in their basal parts. Affinities with the Anthracoptilidae are excluded because they all have numerous anterior concave branches of $\mathrm{CuA}$, while Klebsiella has only one, as in the Blattinopsidae.

The character 'termination of $\mathrm{ScP}$ on RA vs. termination on $\mathrm{C}$ ' is variable within the Paoliidae and the Anthracoptilidae (Prokop et al. 2014; Nel et al. 2015; Guan et al. 2016). Within the known Blattinopsidae, ScP is ending on $\mathrm{C}$; but $\mathrm{ScP}$ strongly approximates RA in Klebsiella, unlike in the other taxa of the family. There are few other differences between Klebsiella and Glaphyrophlebia or Blattinopsis, the most visible ones being the less regular posterior pectination of $\mathrm{RP}$, and the absence of long irregular veinlets in the area between $\mathrm{CuA}$ and $\mathrm{CuP}$ in Klebsiella. These differences are sufficient for a generic separation but not for a separation between two families Blattinopsidae and Klebsiellidae. Thus we reject the unformal identity of Klebsiella with Blattinopsis proposed by Bolton (1928), and we consider that Blattinopsidae and Klebsiellidae are the same families, with a problem of usage vs. potential junior synonymy between the two (see above). 
Type species

Avionblattinopsis oudardi n. sp.

226

227

Diagnosis

228 Forewing characters only. ScP short, ending into RA (unique character among the 229 Blattinopsidae); area between $\mathrm{ScP}$ and $\mathrm{R}$ not extremely narrow, just half as wide as area between $\mathrm{ScP}$ and $\mathrm{C}$; radial vein making a pronounced angle at base of $\mathrm{RP}$, no reticulation in areas between main veins, especially in distal half of wing but only a few crossveins connecting branches of RP and M; area between RA and RP broad; no distinct longitudinal furrows between branches of $\mathrm{RP}$ and $\mathrm{M}$; area between $\mathrm{CuA}$ and $\mathrm{CuP}$ slightly narrower than that between $\mathrm{M}$ and $\mathrm{CuA}$; a concave distal anterior branch of $\mathrm{CuA}$; postcubital-anal area not reticulated, with only four main veins.

236

237

Etymology

Named after the outcrop of Avion and Blattinopsis.

Avionblattinopsis oudardi n. sp.

(Figure 3)

urn:lsid:zoobank.org:act:741B740E-593B-423E-82BC-A303C62F70D5

Etymology

244 Named after our friend and colleague Jacques Oudard, who greatly helps us to collect fossil 245 insects in the site of Avion. 
MNHN.F.A71321 (coll. Patrick Roques, imprint and partial counterimprint of a forewing, with extreme base and a portion of mid part missing).

\section{Type locality}

'Terril N 7' site, Avion, Pas-de-Calais, France.

\section{Stratigraphic occurrence}

Moscovian (Westphalian C/D, equivalent to the Bolsovian/Asturian European local stages).

\section{Diagnosis}

As for the genus.

\section{Description}

Forewing $12.0 \mathrm{~mm}$ long, $3.5 \mathrm{~mm}$ wide; extreme wing base not well preserved, so that the extreme bases of $\mathrm{Cu}, \mathrm{PCu}$ and anal vein cannot be recognized; except for sinuate $\mathrm{R}-\mathrm{RA}$ and ScP, longitudinal veins and branches straight and evenly spaced, often parallel to a marked degree; vein ScP short, terminating on RA, at $5.0 \mathrm{~mm}$ from wing base (near mid wing); area between ScP and RA narrow, about half width of area between $\mathrm{C}$ and ScP; RA sinuate and terminating $9.0 \mathrm{~mm}$ from wing base, RP separating from RA at $2.0 \mathrm{~mm}$ from wing base, RP with a first fork $2.8 \mathrm{~mm}$ from its base, posterior branch simple, anterior branch forked again distally, with posterior branch forked and anterior one simple; $\mathrm{M}$ forked $5.0 \mathrm{~mm}$ from its base, anterior branch forked again very distally; posterior branch forked two times; no longitudinal furrows between branches of RP and MP; few simple crossveins in RP/M area; $\mathrm{M}$ emerging from a common stem $\mathrm{R}+\mathrm{M}$; $\mathrm{CuA}$ with one concave anterior branch and four convex posterior branches; area between $\mathrm{CuA}$ and $\mathrm{M}$ slightly narrower than that between $\mathrm{CuA}$ and $\mathrm{CuP}$; an 
oblique convex arculus in area between $\mathrm{M}$ and $\mathrm{CuA} ; \mathrm{CuA}$ and $\mathrm{CuP}$ separating from a common stem well separated from $\mathrm{M}$ and $\mathrm{PCu}$; $\mathrm{CuP}$ curved at base and straight and strongly concave, while $\mathrm{PCu}$ strongly convex and curved; a short neutral vein between $\mathrm{Cu}$ and $\mathrm{PCu}$ at wing base; in postcubital-anal area, nearly all crossveins all simple, four main veins, all simple, except penultimate one with three branches; network of cells generally lacking except in areas between $\mathrm{M}$ and $\mathrm{CuA}$ and below $\mathrm{PCu}$.

\section{Remark}

Avionblattinopsis gen. nov. can be attributed to the order Paoliida sensu Prokop et al. (2014a) because of the same list of characters indicated above. Affinities with the Paoliidae are excluded for the same reasons as above.

As already noticed, the character 'termination of $\mathrm{ScP}$ on RA vs. termination on $\mathrm{C}$ ' is variable within the Paoliidae and the Anthracoptilidae (Prokop et al. 2014; Nel et al. 2015; Guan et al. 2016). Within the known Blattinopsidae, $\mathrm{ScP}$ is ending on $\mathrm{C}$, unlike in Avionblattinopsis n. gen. But in Klebsiella, ScP is strongly approximating RA before ending on $\mathrm{C}$, supporting the hypothesis that, also in Blattinopsidae, $\mathrm{ScP}$ terminates on RA or on $\mathrm{C}$, depending on the taxa. Avionblattinopsis n. gen. greatly resembles the forewing of the blattinopsid genus Glaphyrophlebia in the organization of the distal branches of RA, RP, M, CuA, and CuP (see Hörnschemeyer and Stapf 2001: fig. 8). More generally, it shares with the Blattinopsidae the presence of only one concave anterior branch of $\mathrm{CuA}$. Many Blattinopsidae have a curved line in the middle of the forewing (vb. sensu Hörnschemeyer and Stapf, 2001). In Avionblattinopsis n. gen., we cannot decide if this structure is present or not because, if present, it would be exactly in the missing part of forewing. 
After the diagnoses of the different genera proposed by Hörnschemeyer and Stapf (2001), Avionblattinopsis n. gen. differs from Stephanopsis and Klebsiella in the area between ScP and R not extremely narrow, just half as wide as area between ScP and C.

More precisely, the type species of Stephanopsis, Stephanopsis incerta (Laurentiaux, 1950) (originally in the genus Blattinopsis) has an area between ScP and RA relatively much narrower than in of Avionblattinopsis n. gen. (Laurentiaux 1950: pl. 1, fig. 1a,b). It differs from Avionblattinopsis $\mathrm{n}$. gen. in the radial vein not making a pronounced angle at base of RP, the area between $\mathrm{CuA}$ and $\mathrm{CuP}$ much broader than that between $\mathrm{M}$ and $\mathrm{CuA}$, and the presence of a reticulation in the areas between main veins. Stephanopsis elegans (Schlechtendal, in Handlirsch 1906) (originally in the genus Blattinopsis) is based on an incomplete forewing, with the area between $\mathrm{C}$ and $\mathrm{ScP}$ not preserved, thus it is not possible to estimate the relative widths of this area compared to that between ScP and R. Nevertheless, it has a straight R, as in the type species of Stephanopsis, and unlike Avionblattinopsis n. gen. Also its area between RA and RP is very narrow (Handlirsch 1906: pl. 16, fig. 8). Stephanopsis mirandus (Richardson, 1956) (originally in the genus Glaphyrokoris Richardson, 1956) has a proportion between the area between $\mathrm{ScP}$ and $\mathrm{R}$ and the area between $\mathrm{C}$ and $\mathrm{ScP}$ very close to that of Avionblattinopsis n. gen., but it differs from Avionblattinopsis n. gen. in the area between $\mathrm{CuA}$ and $\mathrm{CuP}$ as wide as that between $\mathrm{M}$ and $\mathrm{CuA}$ (Richardson, 1956: fig. 18).

Avionblattinopsis n. gen. differs from Klebsiella in the very narrow area between ScP and RA and the pattern of the branches of RP and M.

In Glaphyrophlebia, there are, between all branches of RP and M, distinct longitudinal furrows, starting at the vein-bow or slightly proximad of it and reaching the edge of the wing, unlike in Avionblattinopsis n. gen. and Blattinopsis. But Avionblattinopsis n. gen. and Glaphyrophlebia have no reticulation in the distal half of the wing, and only a few crossveins connecting the branches of RP and M, unlike Blattinopsis. 
Westphaloblattinopsis was originally interpreted as an Archaeorthoptera, with a concave anterior branch of $\mathrm{CuP}$ ending into $\mathrm{CuA}$, unlike all the other Blattinopsidae. This taxon needs to be revised. Nevertheless, it differs from Avionblattinopsis n. gen. in a ScP ending into C, a very narrow area between RA and RP, no concave distal anterior branch of $\mathrm{CuA}$ and an anal area strongly reticulated (Béthoux and Jarzembowski 2010: Fig. 1).

Alienus (A. lebachensis (Goldenberg, 1877)) is based on the mid part of a fore (?) wing, without any diagnostic character (Handlirsch 1906: pl. 37, fig. 29).

Balduriella (B. latissima Meunier, 1925) is based on the distal two-third of a wing. It differs from Avionblattinopsis n. gen. in an anteriorly pectinate anterior branch of RP, and a very long ScP, ending well distal the base of RP. The others structures are hardly discernable on the original photograph of Meunier (1925: fig. 1).

Microblattina (M. perdita Scudder, 1895) is based on an incomplete distal third of a wing, showing no special character that would support and attribution to the Blattinopsidae (Scudder 1895: pl. 3, fig. 5).

Protoblattiniella (P. minutissima Meunier, 1912) is based on a mature nymph of a Polyneoptera (MNHN.F.R51518), blattoid-like, with wing pad rather well-developed (Fig. 4). It has a very broad area between $\mathrm{CuA}$ and $\mathrm{CuP}$, plus anterior branches of $\mathrm{CuA}$, supporting an attribution to the clade Paoliida. But it has only three branches of RP, unlike the Blattinopsidae (Meunier 1912, 1921). It would better fit with the Paoliidae sensu Prokop et al. (2014a).

Rhipidioptera ( $R$. elegans Brongniart, 1893) is based on an incomplete hindwing (MNHN.F.R51226) (Fig. 5). It differs from Avionblattinopsis n. gen. in the very broad reticulated area between $\mathrm{CuA}$ and $\mathrm{CuP}$, and much more branches of RP.

\section{Conclusion}


The revision of Klebsiella shows that this genus can be attributed to the Blattinopsidae, in a genus different from the others. Avionblattinopsis gen. nov. does not fit with any other blattinopsid genera, with the most important difference being the distal fusion of ScP with RA. Of course this character alone could be considered as potentially variable among the Dictyoptera (viz. the roachoid Miroblattites costalis (Laurentiaux-Vieira and Laurentiaux 1987) that has ScP ending into RA in its left wing and in C in its right wing), but it seems to be more stable among the Paoliida. Avionblattinopsis oudardi gen. et $\mathrm{n}$. sp. is not only the first record of the Blattinopsidae from the outcrop of Avion but it increases our knowledge on the biodiversity of this family during the earliest late Carboniferous.

\section{Acknowledgments}

We thank a lot Andrew Ross and an anonymous referee for their helpful comments on the first version of the paper. We also thank Mr. Patrick Wypych, Eiffage Route Nord Est, for his kind authorization to collect fossil insects in the terril of Avion. We thank Dr Gaelle Doiteau (ERecolnat program) for the photographs of the material from Commentry stored at the MNHN.

\section{Disclosure statement}

No potential conflict of interest was reported by the authors.

\section{References}

Béthoux O., Nel A. 2002. Venation pattern and revision of Orthoptera sensu nov. and sister groups. Phylogeny of Palaeozoic and Mesozoic Orthoptera sensu nov. Zootaxa 96:1-88.

Béthoux O., Klass K.-D., Schneider J.W. 2009. Tackling the "Protoblattoidea problem": revision of Protoblattinopsis stubblefieldi (Dictyoptera; Late Carboniferous). European Journal of Entomology 106:145-152. 
Béthoux, O., Jarzembowski E.A. 2010. New basal neopterans from Writhlington (UK,

371 Pennsylvanian). Alavesia 3:87-96.

372 Bolton H. 1925. Fossil insects. 2. Insects from the coal measures of Commentry. British

373 Museum of Natural History, London: 1-56.

374 Brongniart C. 1893. Recherches pour servir à l'histoire des insectes fossiles des temps primaires

375 précédées d'une étude sur la nervation des ailes des insectes. Bulletin de la Société d'Industrie

376 Minérale de Saint-Etienne (3) 7:1-491.

377 Carpenter F.M. 1992. Superclass Hexapoda. In: Moore, R.C., Kaesler, R.L. (eds). Treatise on 378 Invertebrate Paleontology. The Geological Society of America and the University of Kansas, 379 Boulder, Colorado, (R), Arthropoda 4 3/4:xxii + 655 pp.

380 Coty D., Hava J., Prokop J., Roques P., Nel A. 2014. New archaeorthopteran insects from the 381 Late Carboniferous of the Nord and Pas-de-Calais basins in northern France (Insecta: 382 Cnemidolestodea, Panorthoptera). Zootaxa 3878:462-470.

383 Giebel C.G. 1867. Charakteristik mehrerer Schabenflügel aus der Steinkohlenformation von 384 Lobejun. Zeitschrift für die Gesammten Naturwissenschaften 30:416-417.

385 Goldenberg F. 1877. Die fossilen Thiere aus der Steinkohlenformation von Saarbrücken. Fauna 386 Saraepontana Fossilis $2: \mathrm{i}-\mathrm{iv}+1-54$.

387 Guan Zhaoying, Prokop J., Roques P., Lapeyrie J., Nel A. 2015. Revision of the enigmatic 388 family Anthracoptilidae enlightens the evolution of Palaeozoic stem-dictyopterans. Acta 389 Palaeontologica Polonica 61:71-87.

390 Handlirsch A. 1906-1908. Die fossilen Insekten und die Phylogenie der rezenten Formen. Ein 391 Handbuch für Paläontologen und Zoologen. 1430 pp. (Engelman, V.W. publ., Leipzig) 392 [published in parts between 1906 and 1908 as follows: pp. i-vi, 1-160, pls. 1-9 (May 1906); pp. 161-320, pls. 10-18 (June 1906); pp. 321-480, pls. 19-27 (August 1906); pp. 481-640, pls. 28-36 (October 1906); pp. 641-800, pls. 37-45 (February 1907); pp. 801-960, pls. 46-51 (June 
1907); pp. 961-1120 (November 1907); pp. 1121-1280 (January 1908); pp. vii-ix, 1281-1430 (July 1908). Dated from publication information given on p. ix.]

Handlirsch A. 1919. Revision der paläozoischen Insekten. Denkschriften der Kaiserlichen Akademie der Wissenschaften, Mathematisch-Naturwissenschaftliche Klasse 96:511-592.

Handlirsch A. 1922. Animalia Insecta Palaeozoica. Fossilium Catalogus 16:230 pp.

Hörnschemeyer T., Stapf H. 2001. Review of Blattinopsidae (Prothortoptera) with description of new species from the Lower Permian of Niedermoschel (Germany). Neue Jahrbuch für Geologie und Paläontologie, Abhandlungen 221:81-109.

Kukalová J. 1958. Remarks to the family Blattinopsidae Bolton, 1925 (Insecta, Protorthoptera). Vestnik Ustredniho Ustavu Geologickeho 33:129-131.

Laurentiaux D. 1950. Les insectes des bassins houillers du Gard et de la Loire. Annales de Paléontologie 36:63-84.

Laurentiaux-Vieira F., Laurentiaux D. 1987. Un remarquable Archimylacridae du Westphalien inférieur belge. Ancienneté du dimorphisme sexuel des blattes. Annales de la Société Géologique du Nord 106:37-47.

Meunier F. 1908. Quatrième note sur de nouveaux insectes du Stéphanien de Commentry. Bulletin du Muséum National d'Histoire Naturelle 14:244-249.

Meunier F. 1912. Aperçu sur les Protoblattinae et les Mylacrinae du bassin houiller de Commentry (Carbonifère). Annales de la Société Scientifique de Bruxelles 36:187-189.

Meunier F. 1925. Eine neue Blattide (Protoblattinae) aus der Westfalischen Gasflammkohlengruppe. Glueckauf 61:105-107.

Nel A., Roques P., Nel P., Prokin A.A., Bourgoin T., Prokop J., Szwedo J., Azar D., DesutterGrandcolas L., Wappler T. \& Others 2013. The earliest-known holometabolous insects. Nature 503:257-261. 
Nel A., Garrouste R., Prokop J. 2015. The first African Anthracoptilidae (Insecta: Paoliida) near the Permian - Triassic boundary in Kenya. Zootaxa 3925:145-150.

Prokop J., Krzeminski W., Krzeminska E., Hörnschemeyer T., Ilger J.-M., Brauckmann C., Grandcolas P., Nel A. 2014a. Late Palaeozoic Paoliida is the sister group of Dictyoptera (Insecta: Neoptera). Journal of Systematic Palaeontology 12:601-622.

Prokop J., Roques P., Nel A. 2014b. New non-holometabolous insects from Pennsylvanian of Avion locality in Pas-de-Calais, France (Insecta: 'Exopterygota'). Alcheringa 38:155-169.

Prokop J., Tippeltova S., Roques P., Nel A. 2013. A new genus and species of Breyeriidae and wings of immature stages from the Upper Carboniferous, Nord-Pas-de-Calais, France (Insecta: Palaeodictyoptera). Insect Systematics and Evolution 44:117-128.

Richardson E.S.Jr. 1956. Pennsylvanian invertebrates of the Mazon Creek area, Illinois. Insects. Fieldiana Geology 12:15-56.

Schubnel T., Perdu L., Roques P., Garrouste R., Nel A. 2019a. Two new stem-stoneflies discovered in the Pennsylvanian Avion locality, Pas-de-Calais, France (Insecta: 'Exopterygota'). Alcheringa 43:430-435.

Schubnel T., Roberts D., Roques P., Garrouste R., Desutter-Grandcolas L., Nel A. 2019b. Moscovian fossils shed light on the enigmatic polyneopteran families Cacurgidae and Eoblattidae (Insecta: 'Eoblattida', Archaeorthoptera). Journal of Systematic Palaeontology https://doi.org/10.1080/14772019.2019.1627595

Schubnel T., Desutter-Grandcolas L., Legendre F., Prokop J., Mazurier A., Garrouste R., Grandcolas P., Nel A. 2019c. To be or not to be: postcubital vein in insects revealed by microtomography. Systematic Entomology https://doi.org/10.1111/syen.12399

Scudder S.H. 1895. The fossil cockroaches of North America. Proceedings and Transactions of the Royal Society of Canada (4) 12:147-153. 
445 Figure 1. Klebsiella exstincta Meunier, 1908, holotype: MNHN.F. R51219. Photograph of 446 imprint. Scale bar $10 \mathrm{~mm}$.

447 Figure 2. Klebsiella exstincta Meunier, 1908, holotype: MNHN.F. R51219. Photograph of 448 counterimprint. Scale bar $10 \mathrm{~mm}$.

449 Figure 3. Avionblattinopsis oudardi n. gen. et n. sp., holotype: MNHN.F.A71321. Forewing. 450 A, photograph; B, reconstruction. Scale bars $1.0 \mathrm{~mm}$.

451 Figure 4. Protoblattiniella minutissima Meunier, 1912, holotype: MNHN.F.R51518. General 452 habitus. A, dry; B, under alcohol. Scale bars $5.0 \mathrm{~mm}$.

453 Figure 5. Rhipidioptera elegans Brongniart, 1893, holotype: MNHN.F.R51226. General 454 habitus. A, dry; B, under alcohol. Scale bars $5.0 \mathrm{~mm}$. 


\section{$\mathbf{A}$}

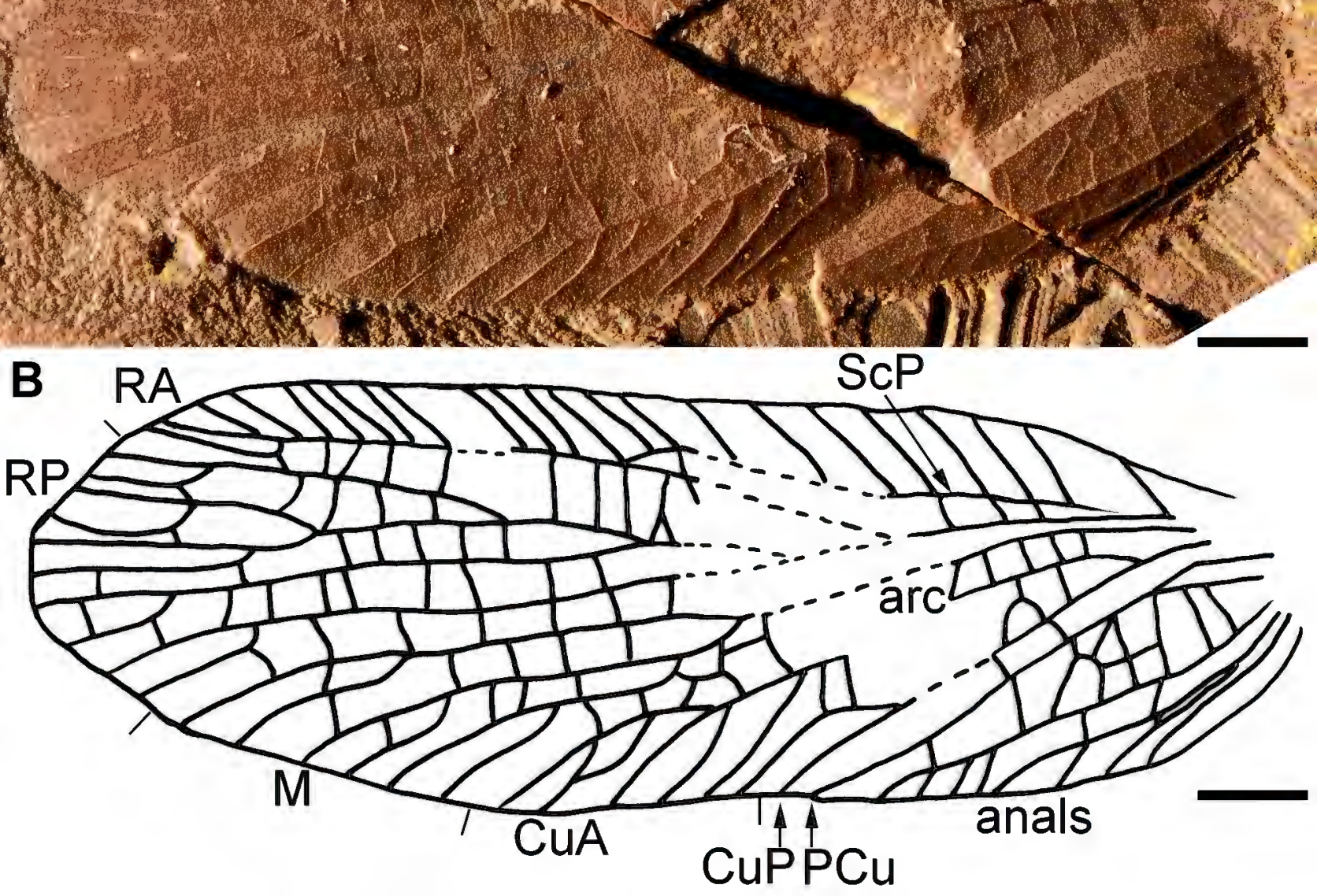




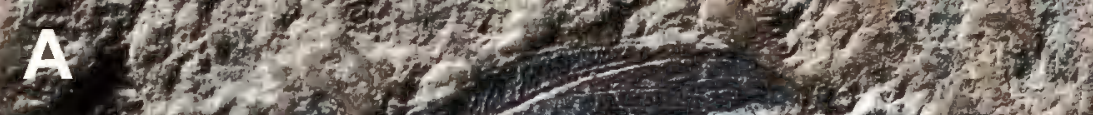

7.

atas

$-1+120$

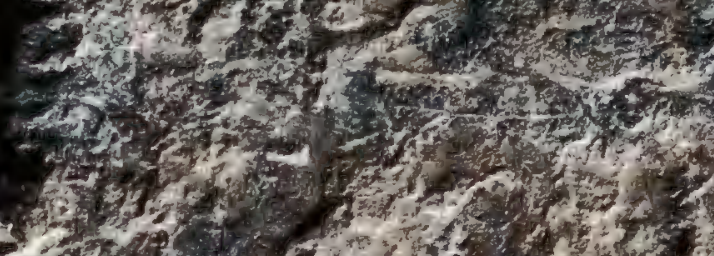

(3)

T. 6

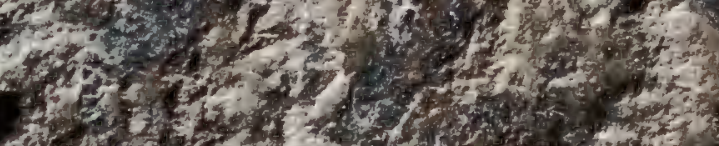
(6) W(2) B 3. $1 x^{2}$

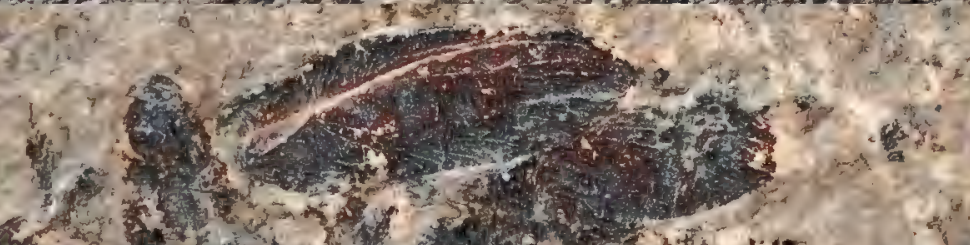

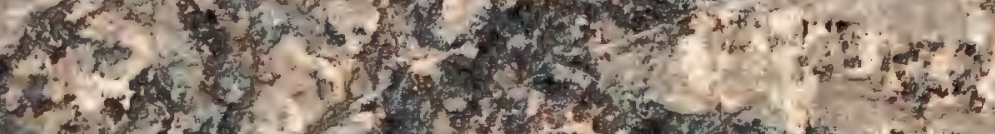

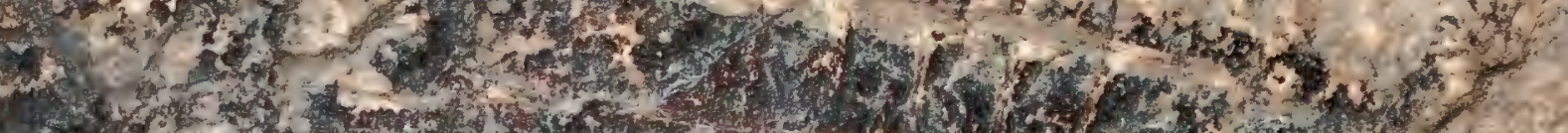
2.7.

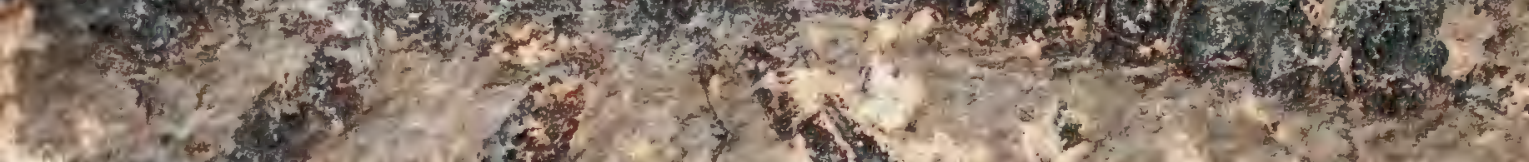
3
1)
63
on
wonn

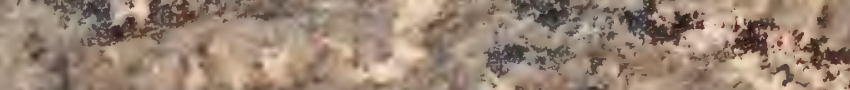
(2)
(2)

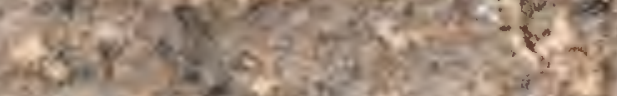
$3^{2}$
it 
